\title{
DIAGNOSTICS OF INFLAMMATORY INSIDE THE PLEURAL COMPLICATIONS OF THORACIC INJURY
}

\author{
Yevgen Kosov, Olena Rozhkova, Victor Veklych, Nikita Barsukov \\ V. N. Karazin Kharkiv National University, 6 Svobody Sq., Kharkiv, 61022, Ukraine, \\ e-mail: med@karazin.ua
}

The non-specificity of the clinical signs of posttraumatic purulent thoracic complications indicates the importance of instrumental diagnostic methods. There is no generally accepted algorithm for examining an injured person with a chest injury that would allow timely recognition of purulent complications in the posttraumatic period. The results of the examination of patients with intra-pleural complications of thoracic injury using the spiral computed tomography method, which in dynamics allows objectively documenting the dynamics of the pathological process, evaluating the effectiveness of treatment, timely diagnose secondary complications, are presented.

KEY WORDS: thoracic trauma, internal pleural complications, diagnosis

\section{ДІАГНОСТИКА ЗАПАЛЬНИХ ВНУТРІШНЬО ПЛЕВРАЛЬНИХ УСКЛАДНЕНЬ ТОРАКАЛЬНОЇ ТРАВМИ}

Косов С. В., Рожкова О. Ю., Веклич В. М., Барсуков Н. В.

Харківський національний університет імені В. Н. Каразіна, пл. Свободи, 6, м. Харків, 61022,

Україна

Не специфічність клінічних ознак посттравматичних гнійних торакальних ускладнень свідчить про значущість інструментальних методів діагностики. Немає загальноприйнятого алгоритму обстеження постраждалих з ушкодженнями грудей, який дозволив би своєчасно розпізнати гнійні ускладнення в посттравматичному періоді. Представлені результати обстеження пацієнтів 3 внутрішньо плевральними ускладненнями торакальної травми за допомогою методу спіральної комп'ютерної томографії яка в динаміці дозволяє об'єктивно документувати динаміку патологічного процесу, оцінити ефективність лікування, своєчасно діагностувати вторинні ускладнення.

КЛЮЧОВІ СЛОВА: торакальна травма, внутрішньо плевральні ускладнення, діагностика

\section{ДИАГНОСТИКА ВОСПАЛИТЕЛЬНЫХ ВНУТРИ ПЛЕВРАЛЬНЫХ ОСЛОЖНЕНИЙ ТОРАКАЛЬНОЙ ТРАВМЫ}

Косов Е. В., Рожкова Е. Ю., Веклич В. Н., Барсуков Н. В.

Харьковский национальный университет имени В. Н. Каразина, пл. Свободы, 6, г. Харьков, 61022,

Украина

Не специфичность клинических признаков посттравматических гнойных торакальных осложнений свидетельствует о значимости инструментальных методов диагностики. Нет общепринятого алгоритма обследования пострадавшего с повреждения груди, который позволил бы своевременно распознать гнойные осложнения в посттравматический период. Представлены результаты обследования пациентов с внутри плевральными осложнениями торакальной травмы с помощью метода спиральной компьютерной томографии, которая в динамике позволяет объективно документировать динамику патологического процесса, оценить эффективность лечения, своевременно диагностировать вторичные осложнения.

КЛЮЧЕВЫЕ СЛОВА: торакальная травма, внутренне плевральные осложнения, диагностика

\section{INTRODUCTION}

(C) Kosov E. V., Rozhkova O. Y., Veklych V. M., Barsukov N. V., 2018
There is an increase in the proportion of breast damages in the structure of injuries in peacetime from $12.5 \%$ in the late 70 s of the 
20th century to $25 \%$ at present [1]. Severe chest injury is the cause of both early mortality due to bleeding and hypoxia, and late mortality associated with the development of septic complications and multiple organ failure [2].

Purulent process due to thoracic trauma may develop as in the pleural cavity and the lungs and heart cavity shirt, mediastinum and chest wall [3]. For posttraumatic purulentinflammatory thoracic complications include the following types of purulent complications: pleural empyema, lung abscess, pericarditis, mediastinitis [4]. Empyema of the pleura - the most common purulent complication, the issues of its diagnosis and treatment are highlighted in the literature quite widely, although most scientific research is based on the analysis of its nontraumatic etiology. According to various data, 7-16\% empyema of the pleura has traumatic etiology [5-6]. However, some other post-traumatic inflammatory complications are devoted to a few publications based on the study of a small number of observations. Post-traumatic lesions are lung abscesses that develop as a result of breast injury, regardless of the nature and severity of the primary lung injury [7].

According to the generalized data, pneumonia develops in $20-40 \%$ of observations after a combined injury [8]. In the event of breast injury, pneumonia develops more often after the gunshot trauma (8-18\%) against the background of blood loss and large hematoma of the lung [5], abscesses of the lungs are found much less frequently - from $0.9 \%$ to $2.8 \%$ [4].

Purulent mediastinitis continues to be one of the most severe forms of generalized surgical infection, worldwide mortality ranges from 23-48\% [4], reaching with anaerobic mediastinitis $68-80 \%$ [6]. High mortality with purulent mediastinitis is connected, first of all, with its later diagnosis. $[2,6]$.

Diagnosis of pleural empyema in spiral computed tomography (SCT) is based on signs such as heterogeneity of the contents of the pleural cavity with gas inclusions and thickening of the pleura leaves [4]. According to [4], using SCT can also diagnose the phase of development of empyema of the pleura and choose a rational volume of intervention in the onset forms of suppuration.
Important information can be obtained from SCT in patients with purulent pulmonary complications [1]. Significant difficulties are the differential diagnosis between the hematoma of the lung and progressive pneumonia on the background of hematomas in the period from 1 to 3 weeks after the closed injury. Similar difficulties are noted in the differentiation of inflammatory changes in the lungs from their damage in case of chest injury [6-7]. SCT - a picture of mediastinitis, according to some data [6], allows to differentiate the nature of the inflammation of cell mediastinum.

Thus, the analysis of domestic and foreign literature suggests that the frequency of posttraumatic purulent thoracic complications has no tendency to decrease, the lethality remains at a very high level. The problem of prediction, diagnosis and treatment of purulent complications of chest damage is not sufficiently studied.

Not specificity of clinical signs of posttraumatic purulent thoracic complications testifies to the importance of instrumental diagnostic methods. Until now, chest X-ray is the most common method of diagnosing chest lesions. The literature data indicate that there is no comparative analysis of the sensitivity of such X-ray methods as ultrasound diagnosis (USD), computer tomography (CT), depending on the nature of the injury and complications. There is no generally accepted algorithm for examination of victims with chest injuries, which would allow timely recognition of purulent complications in the post-traumatic period.

\section{OBJECTIVE}

Improve the outcome of treatment for injuries with injuries and closed chest injury by improving the methods of early diagnosis of inflammatory intra-pleural complications.

\section{MATERIALS AND METHODS}

The results of the examination of patients with intra-pleural complications of thoracic trauma with the help of the SCT method are presented.

In the empyema of the pleura I-II phase, 47 victims were examined, including after chest injury (CI) - (18) and closed chest trauma (CCT) - (29). 42 patients who had pulmonary suppuration, including after injury (7) and CCT (35), were also investigated at 
different times after chest injury. In all observations of pulmonary suppuration after injury, the primary SCT study was performed at the stage of development of purulent process.

At mediastinitis, 27 patients suffered from SCT on different occasions (from day one to four months) after injury (17) and closed injury (10). In all 17 examined patients with mediastinitis after wounds, inflammatory changes of fibrous mediastinum of general or restricted nature were detected. Phlegmon mediastinum was diagnosed in 10 patients early in the post trauma period.

\section{RESULTS AND DISCUSSION}

At empyema of pleura I-II phases in all SCT observations there was a heterogeneity of pathological intra pleural content, its density varied in a wide range, from -30 to +60 ODN. The presence of small inclusions of gas density in the contents of the pleural cavity was found in $91.4 \%$, the horizontal level of the fluid $-12.3 \%$. In the vast majority of patients, the inequality of the contours of the pleura leaves with their thickening was detected $(92.7 \%)$. The nature of the changes in the leaves of the pleura depended on the prescription of the pathological process until the time of the study, the thickness of the parietal leaf varied within 3-11 $\mathrm{mm}$, visceral $-2-7 \mathrm{~mm}$.

According to the SCT, the pleural empyema (EP) was diagnosed in 43 patients, the sensitivity of the method was $91.4 \%$ ( $90.7 \%$ for injuries and $91.7 \%$ for CCT). Mistakenly negative results of SCT were noted in 5 observations of EP, including 2 after wounds and $3-$ after CCT.

The absence of small gas inclusions in the contents of the pleural cavity was the main cause of diagnostic errors. In these observations, the diagnosis was verified with puncture (4) or autopsy (1).

Despite the high sensitivity of the method of SCT in the diagnosis of purulent process, in 7 observations noted the difficulty in determining the exact localization of the pathological process. So in 6 patients, according to SCT, it was not possible to differentiate the EP from the lung abscess. The diagnosis is clarified only with X-ray contrast study after draining purulent foci.

In one observation, the subpleural chronic abscess of the chest wall, which led to the development of osteomyelitis of the ribs, was considered as a pleural empyema in the SCT series. X-ray contrasting pleurography also confirmed the presence of a restricted EP.

The sensitivity of the SCT method to pleural empyema was $91.4 \%$, including $90.7 \%$ for injuries and $91.7 \%$ for closed trauma.

In all observations of pulmonary suppuration after injury, the primary SCT study was performed at the stage of development of purulent process. The pathological process was more often localized in the upper lobe (5), less frequently in the lower (2), but in no observation did not coincide with the anatomical boundaries of segments or lung particle. In three patients, examined at 5-12 days after injury, areas of irregular shape with lesions from 2 to 4 segments of lung, heterogeneous density from -36 to 52 ODN with small inclusions of gas density and increased density of adjacent pulmonary tissue were detected. These changes were treated as abstinent pneumonia with multiple destruction cavities. Two of them in the lung inflammation zone visualized the course of the wound canal in the thickness of the lower lobe. In all three observations, the pathological content in the pleural cavity was visualized, including that which is not differentiated from the pulmonary changes in one of them.

In the study of dynamics (18-28 days), including after the additional drainage of the pleural cavity (2), a decrease in the zone of inflammatory changes with the formation of rounded ones, including multiple (2) cavities with a horizontal fluid level, was noted. In 4 patients, examined for 12-52 days after breast injury, rounded forms of single cavities with a density of gas and liquid (horizontal level) were detected, with a total volume of 15 to $256 \mathrm{~cm}^{3}$. The walls of the cavity had a value of soft tissue density, thickness from 3 to $8 \mathrm{~mm}$, perifocally marked increase in the density of lung tissue. Such changes indicated that there were solid abscesses in the lungs. Drainage bronchi were visualized in three observations. The pathological process was localized within the 2 to 3 segments of the lung.

In the case of closed chest injury, the primary SCT was performed for 1-2 days of hospitalization in 8 patients, later than 5 days in 27. All patients who were examined from 
the first day after CCT, according to SCT, lung changes in the form of polymorphic areas of density increase from 256 to 38 ODN with fuzzy contours, irregular shape, drainage, and with a clear visualization of the bronchial lumen that was considered as a hemorrhagic hemorrhage or a lung injury. In 5 of these, lung tissue ruptures with the formation of cavities in the thickness of the lung tissues filled with liquid density of blood and (or) gas were visualized on the background of the lung. At studying in the dynamics after 7-10 days about the accession of the inflammatory process was indicated by the lack of regression of the slaughtering centers (5) or the growth of infiltrative changes in the lungs, which is not characteristic of the uncomplicated course of the pathological process.

In the remaining 27 patients who were first examined in the stage of development of inflammatory complications, judging by the amount of primary lung damage was not possible. Nevertheless, in 8 of them, thinwalled cavity formation with liquid and (or) gaseous contents was revealed, indicating the traumatic nature of the formations in the lungs. The diagnosis of pulmonary suppuration according to SCT was confirmed in 32 out of 35 patients examined for 12-30 days after CCT, the sensitivity of the method was $91.4 \%$.

SKT signs of abstinence pneumonia (15) were characterized by the presence of polymorphic zones of heterogeneity of the pulmonary tissue with values of soft tissue density and multiple inclusion of round or irregular shape with values of density of liquid and gas. The prevalence of the destructive process varied from 2 to 7 segments, in 3 observations, it was of twosided nature.

In 17 victims, a single lung abscess was found - a rounded form of formation with distinct unequal contours of a heterogeneous structure with small inclusions of gas density or a horizontal level in the total volume from 139 to $580 \mathrm{~cm}^{3}$. The walls of the cavity had a value of the density of soft tissues, their thickness varied from 6 to $9 \mathrm{~mm}$.

The data obtained in the SCT study (the nature of suppuration, the amount and localization of abscesses, proximity to the chest wall, the degree of adequacy of natural drainage in the bronchus) were the basis of the therapeutic tactic in patients with purulent pulmonary complications.

CT false negative results were obtained in three observations during examination of 1318 days after injury. In the first observation, hematoma was detected in the lung $(7 \mathrm{~cm}$ in diameter) on the background of a rounded hemothorax in a volume of $1200 \mathrm{ml}$ and compression of the lungs. In two other observations, lung abscesses were not diagnosed against a background of a limited multi-chamber EP and were visualized only on a re-study after drainage of the pleural cavity. In general, in the case of SCT, the complexity of differentiation of intrapulmonary and intra-pleural content was noted in 6 observations of pulmonary suppuration after CCT.

Thus, the sensitivity of the method in the diagnosis of purulent pulmonary complications was $92.9 \%$, including $100 \%$ in wounds and $91.4 \%$ in CCT.

In all 17 examined patients with mediastinitis after wounds, inflammatory changes of fibrous mediastinum of general or restricted nature were detected. The phlegmon of mediastinum was diagnosed in 10 patients early in the aftermath of the trauma in the form of a zone with values of the density of the fluid of irregular shape, with fuzzy contours, heterogeneous structure due to areas with soft tissue density and 6 observations with gas values. In 2 observations, inflammatory changes were localized throughout the anterior mediastinum, in 5 - in the upper parts of the anterior and posterior mediastinum, and in 3 in the posterior and anterior mediastinum throughout (total mediastinitis). Three patients with combined wounds in the neck and breast, along with inflammatory changes in the mediastinum, also revealed a neck phlegmon in the form of the lack of differentiation of the fiber pretraheal, peripheral and around the vascular spaces, increasing its density to the values of the fluid and inclusion of sites with soft tissue density and gas.

Mediastinal abscess was detected in two injured (after 35 and 60 days after injury) in the form of formation with liquid density values, rounded form, with clear contours, heterogeneous structure due to areas with soft tissue (capsule) densities in the periphery. 
In one case, the formation was located in the upper parts of the anterior mediastinum, in the other - in the lower parts, squeezing the right chambers of the heart. Infiltration of mediastinum was observed in 5 patients, in the dynamics with signs of suppuration in the form of a zone with values of soft tissue density, irregular shape, with fuzzy contours, heterogeneous structure due to sites with values of density of the fluid.

In two cases, infiltrate was localized in the lower parts of the anterior mediastinum, in the other two - in the upper parts of the anterior mediastinum and one in the lower parts of the posterior mediastinum. In three cases, destructive changes in the bone structure of the breast, adjacent to the infiltrate, were discovered.

In 8 out of 10 examined patients with mediastinitis after closed chest trauma during the initial CT study found a broken sternum and retrosternal hematoma in a zone of increased density, irregular shape, with fairly sharp contours. In the study of the dynamics noted an increase in the volume of the hematoma and the emergence of heterogeneity of its structure at the expense of areas with values of density of the fluid and gas sections, which was a sign of hematoma suppuration. In two observations of the closed trauma, destructive changes of the sternoclux joint with the presence of infiltrate in the adjacent parts of the anterior mediastinum in the form of a zone with values of the density of soft tissues of irregular shape, with fuzzy contours, were diagnosed.

Sensitivity of SCT in relation to purulent mediastinitis, regardless of the nature of the damage, was $100 \%$.

\section{CONCLUSION}

Thus, the analysis of the results of the study indicates the need for a comprehensive examination of suspected post-traumatic intra pleural thoracic complications.

In the presence of any manifestations of systemic inflammatory response in the posttraumatic period in patients with chest lesions, regardless of the results of the X-ray examination, ultrasound examination and computed tomography of the chest should be performed, which allows to detect the accumulation of pathological contents in the pleural and pericardial cavity, to assess the nature changes in the pulmonary tissue, mediastinum, thoracic wall and decide on the drainage of lesions fester.

At the same time, for the correct interpretation of some changes in spiral computed tomography, including the lung abscess that developed in the background of pulmonary hemorrhages and mediastinitis against the background of hemorrhages in the mediastinum and pneumomediastinum, it is necessary to compare them with the baseline data. This testifies to the necessity of performing an early spiral computed tomographic examination in patients with chest lesions in the presence of any focal changes on the review X-ray.

Spiral computer tomography of the chest in dynamics allows to objectively document the dynamics of the pathological process, evaluate the effectiveness of treatment, timely diagnose secondary complications.

The application of this algorithm allows to diagnose the entire spectrum of intra-pleural complications in the early stages and to avoid diagnostic errors.

\section{PROSPECTS FOR FUTURE STUDIES}

Detection of the developmental frequency and structure of inflammatory intra-pleural complications of thoracic trauma. Study of distribution and localization of purulent process depending on the nature of damage to the chest. Setting the factors that significantly contribute to the development of septic complications after injury and closed chest trauma. Conducting a comparative evaluation of X-ray methods for diagnosing inflammatory complications of thoracic trauma and developing a diagnostic algorithm.

Thus, the issue of prediction, diagnosis and treatment of inflammatory complications of thoracic trauma is largely unresolved, which is the basis for further research.

\section{REFERENCES}

1. Hadzhibaev A. N., Rakhmanov R. O., Sultanov P. K., Sharipova V. Kh. Diagnostics and surgical tactics for emergency conditions caused by trauma and diseases of the chest cavity organs. // General Resuscitation. 2016. - № 12 (4). - P. 57-67.

2. Agafonova N. V. Radiation methods for diagnosing traumatic injuries of the chest organs in patients with 
polytrauma, problems of diagnostics / N. V. Agafonova, S. V. Konev, A. G. Alekseeva // Proceedings of the XVIII All-Russian Scientific and Practical Conference «Multidisciplinary Hospital: the integration of specialties.» - Leninsk-Kuznetsky, 2014. - P. 57-58.

3. Granhed H. P. A feasibility study of 60 consecutive patients operated for unstable thoracic cage / H. P. Granhed, D. Pazooki // J Trauma Manag Outcomes. - 2014. - Vol. 8, № 1. - P. 20.

4. Chardoli M. Accuracy of chest radiography versus chest computed tomography in hemodynamically stable patients with blunt chest trauma / M. Chardoli, T. Hasan-Ghaliaee, H. Akbari, V. Rahimi-Movaghar // Chin J Traumatol. - 2013. - Vol. 16, № 6. - P. 351-354.

5. Bisenkov L. N. Emergency surgery of the chest and abdomen: a guide for doctors / L. N. Bisenkov, P. N. Zubarev, B. I. Ischenko, V. M. Trofimov, S. A. Shalaev. - SPb: SpetsLit, 2015. - P. 574.

6. Comprehensive treatment of lung abscesses and empyema in patients with severe thoracic injury / V. V. Boyko et al. // Klinicchna hirurgiya. - 2011. - № 3. - P.53-56.

7. Chung J. H. ACR appropriateness criteria blunt chest trauma / J. H. Chung, C. W. Cox, T. L. Mohammed, J. Kirsch, K. Brown, D. S. Dyer, M. E. Ginsburg, E. Heitkamp, J. P. Kanne, E. A. Kazerooni, L. H. Ketai, J. G. Ravenel, A. G. Saleh, R. D. Shah, R. M. Steiner, R. D. Suh // J Am Coll Radiol. - 2014. - Vol. 11, № 4. - P. 345-351.

8. Kochergaev O. V. Efficiency of spiral computed tomography in the detection of lung damage in severe mechanical combined chest injury / O. V. Kochergaev, A. A. Kopalin, V. I. Draznin, V. A. Kotkin // Togliatti Medical Consulium. - 2014. - № 5-6. - P. 59-66. 